\title{
IMPLEMENTASI SER VICE EXCELLENCE OLEH CUSTOMER SERVICE PADA BMT BISMILLAH SUKOREJO
}

\author{
Alif Arfian Syah \\ IAIN Kudus \\ Alifarfiansyah@gmail.com
}

\begin{abstract}
As a well-known microfinance institution in Sukorejo, BMT Bismillah wants to always maintain its existence, by always providing service excellence to its customers so that customers become satisfied and loyal. For service excellence to be carried out, surely there must be a subject or actor who can deliver excellent service which is the main goal. The subject or actor intended is a customer service. BMT Bismillah certainly has service excellence standards that must be applied by customer service. Therefore, the authors are interested in researching how the service excellence implemented by Bismillah Sukorejo BMT customer service by analyzing it using existing standards. The main problem in this study is how the implementation of service excellence standards for services that actually occur in BMT Bismillah carried out by customer service. This type of research is field research by taking the location of research in BMT Bismillah Sukorejo using a qualitative approach. The data in this study consisted of primary data and secondary data obtained using the method of interviews (interviews) with customer service, documentation and observation. The results showed that customer service is able to implement the standards set by BMT Bismillah into services that have become its work, but not just any service but excellent service (service excellence) which includes the basic aspects of Accountability, Action, Attention, Appearance, Attitude, Ability that is able to satisfy and attract customers to remain loyal to BMT Bismillah
\end{abstract}

\section{Kata Kunci: Service Excellence, Customer service, BMT Bismillah BMT Bismillah Prime Service Standards}

\begin{abstract}
Abstrak
Sebagai lembaga keuangan mikro yang ternama di Sukorejo, BMT Bismillah ingin selalu menjaga eksistensinya, dengan senantiasa memberikan service excellence kepada nasabahnya sehingga nasabah menjadi puas dan loyal. Agar service excellence tersebut dapat terlaksana, tentunya harus ada subjek atau pelaku yang dapat menyampaikan pelayanan prima yang menjadi tujuan utama. Subjek atau pelaku yang di maksud adalah seorang customer service. BMT Bismillah tentunya memiliki standar-standar service excellence yang harus di terapkan oleh customer service. Oleh karena itu penulis tertarik untuk meneliti mengenai bagaimana implementasi service excellence yang diterapkan oleh customer service BMT Bismillah Sukorejo dengan mengalisisnya menggunakan standar-standar yang ada. Yang menjadi pokok permasalahan dalam penelitian ini adalah bagaimana implementasi standar service excellence terhadap pelayanan yang sebenarnya terjadi di BMT Bismillah yang di laksanakan oleh customer service. Jenis penelitian ini adalah penelitian lapangan (field research) dengan mengambil lokasi penelitian di BMT Bismillah Sukorejo dengan menggunakan pendekatan kualitatif. Data-data dalam penelitian ini terdiri dari data primer dan data sekunder yang diperoleh dengan menggunakan metode interview (wawancara) dengan customer service, dokumentasi dan observasi. Hasil penelitian menunjukkan bahwa customer service mampu mengimplementasikan standar-standar yang sudah ditetapkan oleh BMT Bismillah kedalam pelayanan yang sudah menjadi tugasnya, namun bukan sembarang pelayanan tapi pelayanan prima (service excellence) yang meliputi aspek dasar Accountability (Tanggung Jawab), Action (Tindakan), Attention (Perhatian), Appearance (Penampilan), Attitude (Sikap), Ability (Kemampuan) yang mampu memuaskan dan menarik hati nasabah agar tetap loyal kepada BMT Bismillah.
\end{abstract}

Keyword: Service Excellence, Customer service, BMT Bismillah, Standar Pelayanan Prima BMT Bismillah

\section{5 | B a l a n c a}

Jurnal Ekonomi dan Bisnis Islam

Volume 2 Nomor 1, Januari - Juni 2020 (15 - 23) 


\section{Pendahuluan}

Baitul Maal Wa Tamwil atau BMT sebagai lembaga keuangan mikro kini telah berkembang dimana-mana dan mengalami persaingan yang ketat, Di barengi dengan datangnya wacana MEA (Masyarakat Ekonomi ASEAN) yang akan menambah kompleksnya permasalahan persaingan, sehingga menuntut lembaga keuangan untuk meningkatkan profesionalitas dan daya saing agar tidak tergeser oleh lembaga keuangan asing dalam mendapatkan nasabah untuk memasarkan produknya. Saat ini persaingan lembaga keuangan tidak hanya bertumpu pada produknya saja, melainkan bertumpu pada pelayanan yang disediakan. Hal ini dikarenakan dalam usaha lembaga keuangan konvensional maupun syariah berusaha mengemas sedemikian rupa dalam menjual produk maupun jasanya agar dapat menarik nasabah, maka dalam sebuah usaha lembaga keuangan pelayanan prima menjadi prioritas utama dalam kegiatan operasionalnya, sehingga mampu bertahan dalam iklim persaingan yang ketat.

Selain dari UUD 1945 pasal 33, BMT juga diatur khusus dengan Keputusan Menteri Negara Koperasi dan Usaha Kecil Menengah Republik Indonesia No.91/Kep/M.KUKM/IX/2004 tentang petunjuk pelaksanaan kegiatan usaha koperasi jasa keuangan syariah. Keputusan ini berkaitan dengan segala sesuatu yang terkait dengan pendirian dan pengawasan BMT berada di bawah Departemen Koperasi dan Usaha Kecil Menengah.

Baitul maal wattamwil (BMT) terdiri dari dua istilah, yaitu baitul maal dan baitul tamwil. Baitul maal lebih mengarah pada pengumpulan dana dan penyaluran dana yang bersifat non profit, seperti zakat, infaq, sodaqoh. Sedangkan baitul tamwil mengarah pada pengumpulan dan penyaluran dana yang bersifat komersial, kemudian usaha-usaha tersebut menjadi bagian yang tak terpisahkan dari BMT sebagai lembaga pendukung ekonomi masyarakat mikro dengan berlandaskan syariah. ${ }^{1}$

Baitul Maal wat Tamwil sebenarnya merupakan dua kelembagaan yang menjadi satu, yaitu lembaga Baitul Maal dan lembaga Baitul Tamwil yang masing-masing keduanya memiliki prinsip dan produk yang berbeda meskipun memiliki hubungan yang erat antara keduanya dalam menciptakan suatu kondisi perekonomian yang merata dan dinamis. $^{2}$

BMT kini mengalami perubahan yang besar, dengan cara membuat peran bank sedikit tergeser karena kelebihan BMT sebagai penggerak keuangan mikro yang di minati masyarakat dan juga kebanyakan masyarakat yang bersifat unbankable, BMT berhasil mengakomodasi budaya lokal dalam aspek operasionalnya. Kini BMT tak sulit ditemui karena BMT ada disetiap sudut kota besar maupun kecil, di tengah kegiatan masyarakat maupun di pasar-pasar. Sehingga BMT mampu menjangkau seluruh lapisan masyarakat luas.

BMT Bismillah adalah salah satu BMT yang bertempat di Sukorejo. Tentunya BMT Bismillah bukan satu-satunya lembaga keuangan mikro yang berdiri di wilayah Sukorejo, namun banyak BMT bahkan banyak Bank yang juga berada di wilayah tersebut. Setiap lembaga keuangan khususnya BMT tentunya ingin mencapai suatu keberhasilan. Untuk mencapai hal tersebut, BMT memerlukan strategi untuk menghadapi persaingan yang saat ini semakin lama semakin ketat.

Terdapat berbagai tantangan dalam mencapai keberhasilan. Untuk mengantisipasinya, BMT dituntut untuk dapat

${ }^{1}$ Heri Sudarso, Bank dan Lembaga Keuangan Syariah, (Yogyakarta : Ekonisia, 2003), hlm 96.

2 Jamal Lulail Yunus, Manajemen Bank Syariah, (Malang : UIN Malang Press, 2009), hlm 33.

\section{6| B a l a n c a}


bekerja dengan baik dengan menggunakan berbagai macam sumber daya yang dimiliki, mulai dari cleaning service, satpam sampai direkturnya. Mereka semua harus terlibat dalam memberikan sebuah pelayanan yang bermutu sehingga tidak hanya front linner saja yang dapat memberikan pelayanan namun masing-masing harus memiliki tekad yang kuat demi terciptanya sebuah pelayanan prima yang diberikan oleh BMT. Agar tercipta sebuah service excellence terdapat dua tujuan yang sama, nasabah menginginkan pelayanan yang memuaskan dan BMT selaku penyedia jasa harus memberikan kepuasan kepada nasabah. Saat kedua tujuan tersebut telah ada maka tugas BMT adalah melakukan upayaupaya salah satunya menerapkan standar service excellence dengan inovasi dan kreasi agar kedua tujuan tersebut terlaksana. Agar service excellence terwujud dengan optimal pelayanan harus berorientasi pada kepentingan dan kebutuhan para nasabah.

Keberhasilan dari pemberian kualitas pelayanan itu ditunjukkan para nasabah dengan adanya rasa puas dari para nasabah. Semakin tinggi tingkat kepuasan para nasabah, itu berarti semakin baik pengelolaan pelayanan yang diberikan BMT kepada nasabah. Kenyataannya, antara harapan nasabah dengan kenyataan pelayanan yang diberikan kepada nasabah sering kali terjadi sebaliknya. Tidak sedikit nasabah yang mengungkapkan kritikan dan keluhan karena pelayanan yang diberikan kurang atau bahkan tidak memuaskan. Bahkan ada juga nasabah yang tidak merasa puas namun tidak menyampaikan keluhan dan langsung beralih ke BMT lain. Kritikan dan keluhan tersebut yang dapat menimbulkan persepsi negatif nasabah. Apabila hal tersebut dibiarkan terusmenerus dapat menurunkan tingkat kepercayaan nasabah. Bukan menjadi hal yang tidak mungkin apabila nasabah beralih ke BMT lain karena mereka merasa BMT lain lebih mampu memberikan pelayanan yang dapat memuaskan mereka. Tak hanya di bayangi akan kekhawatiran nasabah akan lebih memilih di layani oleh BMT pesaing namun kini Bank juga mulai membidik sasaran usaha mikro sebagai sumber pendapatannya, otomatis BMT harus memutar otak agar tidak tergeser oleh pesaing dan tetap eksis dan dapat melayani kebutuhan masyarakat mikro.

Dalam kegiatan operasionalnya, BMT hendaknya memiliki sumber daya yang diharapkan mampu menjalankan fungsi sebagai resepsionis, deskman, salesman, customer relation officer, dan komunikator. ${ }^{3}$ Sumber daya yang dimaksud adalah seorang customer service. Tak hanya dibutuhkan seorang customer service, namun juga seorang customer service yang profesional karena peran customer service sangat penting dan vital dalam meningkatkan pelayanan serta upaya mempromosikan citra baik BMT Bismillah. Oleh karena itu, customer service dituntut harus memiliki kemampuan melayani nasabah secara tepat dan cepat serta memiliki kemampuan berkomunikasi yang baik didukung dengan tersedianya sarana dan prasarana yang mendukung kecepatan, ketepatan, dan keakuratan pekerjaannya sehingga dapat memberikan pelayanan yang terbaik bagi kepuasan nasabah, maka dibutuhkan service excellence atau disebut dengan pelayanan prima. Menurut Swastika definisi pelayanan prima mengandung tiga hal pokok, yaitu 1. Adanya pendekatan sikap yang berkaitan dengan kepedulian kepada pelanggan, 2. Upaya melayani dengan tindakan yang terbaik dan 3. Ada tujuan untuk memuaskan pelanggan dengan berorientasi pada standar layanan tertentu.

\section{Landasan Teori}

\section{A. Customer Service}

Customer service adalah setiap kegiatan yang diperuntukkan atau ditujukan untuk memberikan kepuasan kepada nasabah

\footnotetext{
${ }^{3}$ Kasmir, Etika Customer Service, (Jakarta :
} PT. Raja Grafindo Persada, 2008), hlm. 23.

\section{7| B a l a n c a}


melalui pelayanan yang dapat memenuhi keinginan dan kebutuhan nasabah. ${ }^{4}$

Tugas pokok Customer service adalah membantu nasabah untuk memberikan informasi dan formulir, membantu menyelesaikan pengaduan nasabah, memperkenalkan produk-produk atau jasajasa perusahaan, memberikan informasi mengenai fitur dan layanan perusahaan, mempertahankan nasabah agar tetap setia pada perusahaan dan juga menarik nasabah yang baru. ${ }^{5}$

Syarat-syarat yang harus dipenuhi oleh customer service:

\section{Persyaratan Fisik}

Seorang customer service harus memiliki ciri-ciri fisik yang menarik. Ciri tersebut dilihat dari segi wajah, tinggi badan ideal, berat badan ideal. Selain itu customer service juga harus memiliki jiwa yang sehat, tak hanya jiwa tapi rohaninya pun juga harus sehat.

\section{Persyaratan Mental}

Persyaratan mental yang dimaksud adalah seorang customer service harus mempunyai sifat percaya diri sehingga dapat meyakinkan nasabah. Jika percaya diri sudah dimiliki maka perilaku sabar, ramah, murah senyum serta tanggung jawab akan mengikuti apapun kondisinya meski nasabah sedang menyampaikan kemarahan atau komplain.

3. Persyaratan Kepribadian

Customer service harus memiliki kepribadian yang baik saat bertemu dengan nasabah, sehingga muncul kesan pertama yang mengesankan (first impression). Kesan pertama tidak dapat di buat namun di upayakan dari hati berperilaku sopan, ramah, murah senyum, bersifat humor jika diperlukan, gesit, enerjik, mampu mengendalikan diri, tidak mudah terpancing emosi maupun terhadap hal-hal negatif, tidak

${ }^{4}$ Kasmir, Pemasaran Bank, Jakarta : Kencana Prenada Media Grup, 2004), hlm. 202.

5 Nina Rahmayanty, Manajemen Pelayanan Prima, (Yogyakarta : Graha Ilmu, 2013), hlm. 204. mudah marah, dan gerakan tubuh yang sesuai.

4. Persyaratan Sosial

Customer service harus memiliki jiwa sosial yang tinggi, mudah bergaul dengan semua kalangan dan memiliki budi pekerti luhur. ${ }^{6}$

\section{B. Service Excellence}

Pelayanan adalah bagian dari marketing. Falsafah yang mendasari kegiatan usaha bank adalah kepercayaan masyarakat. Terciptanya kualitas layanan tentunya akan menciptakan kepuasan terhadap pengguna layanan, yang pada akhirnya dapat memberikan beberapa manfaat, diantaranya terjalin hubungan yang harmonis antara penyedia jasa dengan nasabah, memberikan dasar yang baik bagi terciptanya loyalitas nasabah dan membentuk suatu rekomendasi dari mulut ke mulut (wordof-mouth) yang menguntungkan bagi penyedia jasa tersebut.

Pelayanan prima adalah kepedulian kepada pelanggan dengan memberikan layanan terbaik untuk memfasilitasi kemudahan pemenuhan kebutuhan dan mewujudkan kepuasannya, agar mereka selalu loyal kepada organisasi/perusahaan. ${ }^{7}$

Pelayanan prima memiliki beberapa pengertian yaitu: ${ }^{8}$

1. Layanan prima adalah pelayanan yang sangat baik dan melampaui harapan pelanggan. Awalnya pelanggan memiliki harapan yang sederhana dan sementara dibenaknya yang bersifat biasa dengan standar yang umum yang banyak diberikan oleh perusahaan lainnya namun ternyata adanya pelayanan ekstra yang tidak diduga dan merupakan surprise dari pelayanan perusahaan seperti seorang nasabah mendapatkan email ucapan ulang

${ }^{6}$ Kasmir, Etike a Customer Service, hlm. 194.

7 A.A. Barata, Dasar-dasar Pelayanan Prima, (Jakarta : PT. Elex Media Komputindo, 2006), hlm. 20 .

8 Nina Rahmayanty, Manajemen Pelayanan Prima, hlm. 17.

\section{8 | B a l a n c a}

Jurnal Ekonomi dan Bisnis Islam

Volume 2 Nomor 1, Januari - Juni 2020 (15 - 23) 
tahun dari perusahaan perbankan tempat ia menabung, maka nasabah akan merasa diberikan perhatian khusus dan merasa dihargai.

2. Layanan Prima adalah pelayanan yang memiliki ciri khas kualitas (quality nice). Ciri khas kualitas yang baik meliputi kemudahan, kecepatan, ketepatan, kehandalan dan emphaty dari petugas pelayanan dalam pemberian dan penyampaian pelayanan kepada pelanggan yang berkesan kuat yang dapat langsung dirasakan pelanggan waktu itu dan saat itu juga.

3. Layanan Prima adalah pelayanan dengan standar kualitas yang tinggi dan selalu mengikuti perkembangan kebutuhan pelanggan setiap saat, secara konsisten dan akurat (handal). Berorientasi kepada kepuasan pelanggan, selalu mengikuti perkembangan standar Internasional/ISO, dan menerapkan manajemen mutu total/konsistensi dan kesadaran mutu yang tinggi (high qualitiy consciouness) seperti customer orientation (fokus pelanggan), robotics, QC-Circles (siklus kendali mutu), automation (otomatisasi), discipline in the workplace (disiplin), qualitiy improvement (Perbaikan mutu), zero defects (kerusakan nol), dan sebagainya.

4. Layanan Prima adalah pelayanan yang memenuhi kebutuhan praktis (practical needs) dan kebutuhan emosional (emotional needs) pelanggan. Kebutuhan praktis meliputi nilai yang dirasakan dengan bentuk berwujud fisik (tangible) dan kebutuhan emosional yang dirasakan kepada fisiologis pelanggan.
Tujuan dari service excellence atau pelayanan prima yaitu: ${ }^{9}$

1. Tujuan pelayanan prima dapat memberikan rasa puas dan kepercayaan pada konsumennya. Dalam pelaksanaanya pelayanan prima merupakan pelayanan yang sangat baik dan melampaui harapan pelanggan dan pelayanan yang memiliki ciri khas kualitas (quality nice). Kualitas memberikan suatu dorongan kepada pelanggan untuk menjalin hubungan yang kuat dengan pelanggan. Kebutuhan yang sesuai dengan rasa dan nilai subjektif kepada pelanggan. Dalam jangka waktu yang panjang perusahaan yang akan tetap bertahan hidup dalam menghadapi persaingan bisnis yang mengglobal adalah perusahaan yang terus melakukan perbaikan dalam kegiatan pelayanan, operasional dan jasa atau inovasi produk untuk selalu meningkatkan kualitas.

2. Tujuan pelayanan prima tetap menjaga dan merawat (maintenance) agar pelanggan merasa diperhatikan dan dipentingkan segala kebutuhannya atau keinginannya. Pelayanan dengan standar kualitas yang tinggi dan selalu mengikuti perkembangan kebutuhan pelanggan setiap saat, secara konsisten dan akurat (handal).

3. Tujuan pelayanan prima merupakan upaya mempertahankan pelanggan agar tetap loyal untuk menggunakan produk barang atau jasa yang ditawarkan tersebut.

\section{Landasan Hukum}

Landasan hukum menurut Al-Qur'an bahwa menjadi seorang customer service salah satu tugasnya adalah memberikan segala informasi yang di butuhkan nasabah maupun yang di amanatkan BMT untuk di sampaikan kepada nasabah. Allah SWT berfirman:

9 Nina Rahmayanty, Manajemen Pelayanan Prima, hlm. 8.

\section{9| B a l a n c a}

Jurnal Ekonomi dan Bisnis Islam

Volume 2 Nomor 1, Januari - Juni 2020 (15 - 23) 




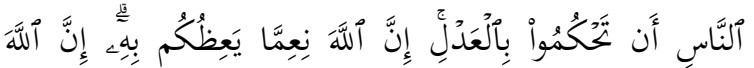

$$
\text { كَانَ سَمِيعُا بَصِير }
$$

Artinya:

"Sesungguhnya Allah menyuruh kamu menyampaikan amanat kepada yang berhak menerimanya, dan (menyuruh kamu) apabila menetapkan hukum di antara manusia supaya kamu menetapkan dengan adil. Sesungguhnya Allah memberi pengajaran yang sebaikbaiknya kepadamu. Sesungguhnya Allah adalah Maha Mendengar lagi Maha Melihat." (QS. An-Nisa': 58). ${ }^{10}$

Allah SWT berfirman:

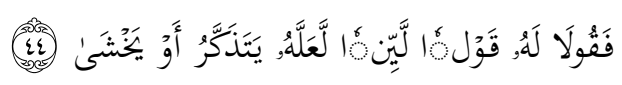

Artinya:

"maka berbicaralah kamu berdua kepadanya dengan kata-kata yang lemah lembut, mudahmudahan ia ingat atau takut." (QS. Thaha: 44). ${ }^{11}$

\section{Metode Penelitian}

Jenis penelitian ini adalah penelitian lapangan dengan pendekatan kualitatif. Penelitian kualitatif menurut Bogdan dan Taylor adalah suatu prosedur penelitian yang bertujuan untuk menghasilkan data deskriptif berupa kata-kata tertulis atau lisan dari orangorang dan perilaku mereka yang dapat diamati. ${ }^{12}$ Dalam penelitian ini penulis mengambil pokok bahasan service excellence di BMT Bismillah Sukorejo sebagai studi kasus penelitian.

${ }^{10}$ Departemen Agama RI, Al-Qayyum AlQur'an dan Terjemahannya Disertai Transliterasi, (Semarang : PT. Karya Toha Putra), hlm. 162.

11 Departemen Agama RI, Al-Qayyum AlQur'an dan Terjemahannya Disertai Transliterasi, hlm. 606.

12 Dikutip dari Lexy J. Moleong, Metodologi Penelitian Kualitatif, (Bandung : Remaja Rosdakarya, 2007), hlm. 3.

\section{Hasil Penelitian}

Implementasi Service Excellence oleh Customer service

Ability (Kemampuan) Front Line sudah sesuai standar yang dikeluarkan oleh BMT Bismillah, customer service berkomunikasi dengan nasabah, selalu menggunakan Bahasa Jawa Kromo Inggil, kecuali nasabah menginginkan menggunakan Bahasa Indonesia maka customer service harus mengikuti keinginan nasabah. Selain berkomunikasi secara verbal, customer service BMT Bismillah sudah mampu menerapkan berkomunikasi dengan bahasa tubuh, yaitu mengekspresikan rasa hormat, menghargai, berterimakasih, tulus, senang melayani. Kemampuan lainnya yaitu menggunakan alat komunikasi sudah barang tentu dikuasai dan sudah sesuai standar, kemudian mengusai produk-produk BMT seperti, apa saja produk BMT, berapa masing-masing bagi hasilnya, apa saja manfaatnya, bagaimana syarat untuk mendapatkan produk tersebut sudah sangat dikuasai oleh customer service. Berikut adalah pada saat customer service melaksanakan pelayanan pada saat nasabah mengajukan pembiayaan, pada saat customer service memperkenalkan produk-produk BMT Bismillah, pada saat customer service membuat buku tabungan atau deposito untuk nasabah, pada saat customer service menginformasikan kepada nasabah mengenai jadwal realisasi pembiayaan (Melalui telepon).

Attitude (Sikap) yang seharusnya ditunjukkan kepada nasabah yaitu ramah, murah senyum, lemah lembut dalam bertutur kata, jujur dalam memberikan setiap informasi kepada nasabah, hormat selalu menganggukkan kepala dan membunggkukkkan badan saat bersapaan dengan nasabah, selalu antusias saat nasabah berbicara, pandai bergaul sehingga nasabah baru dapat dengan cepat akrab dengan customer service. Namun semua sikap yang di tunjukkan harus berasal dari hati, intinya 
tidak di buat-buat atau sesuai standar jadi terlihat kaku.

Apearance (Penampilan) jika berhubungan dengan penampilan, customer service hanya mengikuti sesuai arahan dari manajemen atau sesuai standar yang ada dan tidak berpenampilan berpenampilan yang berlebihan karena akan mengganggu pekerjaan dan kemungkinan nasabah tidak akan fokus terhadap apa yang di jelaskan namun akan fokus pada penampilan customer service yang berlebihan.

Attention (Perhatian) yang diberikan oleh customer service BMT Bismillah yaitu pada saat nasabah terlihat bingung atau resah dengan antrian yang lama maka customer service akan menyapa dan memberi pengertian untuk menunggu sebentar, dan karena di BMT Bismillah tidak ada nomor antrian untuk mendapatkan pelayanan customer service maka customer service harus tetap memperhatikan customer mana yang datang lebih dulu. Perhatian lain di tunjukkan dengan menanyakan kabar (jika sudah mengenal nasabah) atau usaha maupun pekerjaan yang di geluti nasabah agar nasabah lebih merasa dihargai dan diperhatikan, selain itu jika nasabah membawa serta anaknya, maka customer service tak segan untuk memberi pujian yang pas atau menanyakan nama maupun sedang duduk di kelas berapa, perhatian lain yang dapat ditunjukkan yaitu jika nasabah, tidak terlihat datag ke BMT Bismillah untuk beberapa hari, maka customer service biasanya menanyakan keberadaan nasabah beberapa hari lalu, bukan bermaksud ingin tahu namun itu menunjukkan perhatian kepada nasabahnya

Action (Tindakan/Ucapan) oleh customer service sangat penting di jaga, karena jika customer service salah memilih kata-kata maka nasabah akan tersinggung dan enggan untuk kembali di layani oleh customer service. Maka konsentrasi dan fokus saat bekerja itu sangat penting agar tidak bertindak atau mengucapkan kata-kata yang dapat menyinggung perasaan nasabah.

Standar Accountability (Tanggung Jawab) semua bidang pekerjaan, tidak terkecuali sebagai seorang customer service memiliki tanggung jawab masing-masing. Customer service dituntut harus memiliki tekad kuat untuk memenuhi semua hak nasabah, seperti berusaha tidak melakukan kesalahan, berusaha memberikan informasi yang jujur, dan lain sebagainya. Walaupun dalam kenyataannya kita tidak dapat memberikan pelayanan yang benar-benar sesuai standar tapi setidaknya kita sudah mempunyai tekad sebagai perwujudan tanggung jawab terhadap bidang pekerjaan customer service ini.

\section{Pembahasan}

Sikap yang ditunjukkan oleh customer service BMT Bismillah jika di lihat memang tidak kaku, customer service selalu ramah kepada siapa saja baik nasabah yang lama maupun baru. Baik nasabah yang sudah kenal maupun yang belum kenal. Dan customer service tidak segan di ajak diskusi mengenai hal apa saja pada saat tidak ada pekerjaan, tentunya selama diskusi tersebut masih dalam batas pekerjaan maupun kegiatan BMT lain.

Namun pada poin menyebutkan nama diri (customer service), mempersilahkan nasabah duduk dan menyampaikan keinginan untuk membantu terkadang tidak disampaikan oleh customer service. Hal tersebut terjadi karena, sebelum customer service menawarkan bantuan terkadang nasabah sudah mendahului menyampaikan kepada customer service tentang kebutuhannya datang ke BMT misalnya untuk mengajukan pembiayaan, atau untuk memperbarui buku tabungan dan kebutuhan lain. Faktor lain disebabkan karena jarak tempat tunggu nasabah dengan meja customer service hanya berjarak tiga langkah sehingga pergantian nasabah pertama ke nasabah selanjutnya, customer service tidak dapat memberikan sapaan dengan berdiri. Kekurangan lain akibat terlalu dekat jarak 
antara tempat tunggu nasabah dengan meja customer service sehingga semua pembicaraan nasabah dan customer service bisa di dengar oleh nasabah lain, oleh karena itu privasi nasabah tidak bisa di jaga oleh BMT.

Kemudian pada saat menerima telepon, bahasa yang digunakan adalah Bahasa Indonesia tapi jika lawan bicara berbicara dengan Bahasa Jawa maka customer service wajib beralih ke Bahasa Jawa.

\section{Kesimpulan}

Berdasarkan penelitian yang telah penulis paparkan sebelumnya, bahwa ability (kemampuan) seorang customer service harus memiliki kemampuan mengatasi setiap keluhan nasabah, menguasai produk-produk BMT, berkomunikasi yaitu mampu mengerti harapan dan keinginan nasabah, berkemampuan menjelaskan informasi apa saja yang di butuhkan nasabah.

Attitude (Sikap) seorang customer service harus ramah, murah senyum, lemah lembut dalam bertutur kata, jujur dalam memberikan setiap informasi kepada nasabah, hormat selalu menganggukkan kepala dan membunggkukkkan badan saat bersapaan dengan nasabah, selalu antusias saat nasabah berbicara, pandai bergaul.

Appearance (Penampilan) penampilan yang ditunjukkan oleh customer service BMT Bismillah baik secara fisik (pakaian, sepatu, asesoris tata rias muka) maupun non-fisik (kepribadian positif) yaitu rapi dan sederhana namun mampu merefleksikan kepercayaan, kredibilitas, kehormatan diri dihadapan nasabah.

Attention (Perhatian) atau kepedulian penuh kepada nasabah sudah di terapkan oleh customer service BMT Bismillah mulai dari memberi perhatian pada saat nasabah resah menunggu antrian dan memperhatikan kebutuhan dan keinginan nasabah yang lain.

Action (Tindakan/Ucapan) yang harus dilaksanakan meliputi ucapan (greeting), external indirect contact (pertelepon), internal call (telepon internal), oper panggilan telepon, etika bertelepon, etika saat berdiri, etika saat duduk, etika jabat tangan, etika saat berbicara semuanya harus di lakukan dengan benar agar apa yang di lakukan oleh customer service dapat membuat nasabah merasa dilayani dengan baik. Tindakan atau ucapan yang ditunjukkan oleh customer service BMT Bismillah hampir sudah memenuhi standar walapun ada beberapa yang terkadang belum di laksanakan oleh customer service. Tindakan atau kegiatan nyata yang harus dilakukan dalam memberikan pelayanan kepada nasabah.

Accountability (Tanggung Jawab) customer service meliputi bila melakukan kesalahan, bila mengecewakan nasabah, bila membuat nasabah lama menunggu, bila tidak bisa menepati janji, bila mendapat komplain nasabah, bila mendapat kritik dan saran dari nasabah. Kesalahan-kesalahan tersebut memang tidak dapat dihindari namun sebagai customer service harus dapat mengambil hati nasabah dengan menangani langsung masalah yang timbul.

\section{Saran}

Saran yang dapat disampaikan penulis dari penelitian yang telah di lakukan adalah perlunya peningkatan penerapan terhadap standar pelayanan prima yang ada oleh customer service, jika pelayanan sudah baik maka nasabah akan puas dan loyal sehingga pendapatan BMT juga akan meningkat.

Perlu adanya sanksi atau teguran saat customer service tidak memenuhi standar pelayanan prima yang sudah di tetapkan oleh BMT Bismillah.

Pada meja customer service hendaknya dilengkapi semua fasilitas yang dibutuhkan guna memperlancar pelayanan kepada nasabah, khususnya printer+fotocopy yang rusak hendaknya segera diperbaiki agar customer service tidak kesulitan masuk ke back office untuk memfotocopy berkas nasabah yang perlu di gandakan.

\section{2 | B a l a n c a}


BMT Bismillah perlu menggunakan sistem nomor antrian untuk nasabah yang akan menggunakan layanan customer service agar para nasabah dapat disiplin antri dan jelas kapan nasabah akan mendapat layanan.

BMT Bismillah perlu menambah kursi tunggu bagi nasabah agar saat antri tidak berdiri serta menambah kenyamanan nasabah.

\section{DAFTAR Pustaka}

Heri Sudarso. 2003. Bank dan Lembaga Keuangan Syariah. Yogyakarta: Ekonisia

Jamal Lulail Yunus. 2009. Manajemen Bank Syariah. Malang: UIN Malang Press

Kasmir. 2008. Etika Customer service. Jakarta: PT. Raja Grafindo Persada

Kasmir. 2004. Pemasaran Bank. Jakarta: Kencana Prenada Media Grup

Nina Rahmayanty. 2013. Manajemen Pelayanan Prima. Yogyakarta: Graha Ilmu

A.A. Barata. 2006. Dasar-dasar Pelayanan Prima. Jakarta: PT. Elex Media Komputindo

Departemen Agama RI. Al-Qayyum AlQur'an dan Terjemahannya Disertai Transliterasi. Semarang: PT. Karya Toha Putra

Dikutip dari Lexy J. Moleong. 2007. Metodologi Penelitian Kualitatif. Bandung: Remaja Rosdakarya 